\title{
PEMIKIRAN EKONOMI IBNU TAIMIYAH
}

\section{Fasiha \\ Fakultas Ekonomi dan Bisnis Islam Institut Agama Islam Negeri (IAIN) Palopo \\ Email : fasiha@iainpalopo.ac.id}

\begin{abstract}
The development of Islamic economics can not be separated from the historical development of Islamic civilization. The study of the history of economic thought by analyzing the description of economic thinking Ibn Taymiyyah and the history of life that affect the economic thinking of Ibn Taymiyyah. According to Ibn Taymiyyah pricing by the government is good, but not absolute, because the actual prices are set by the forces of demand and supply. Another case, if the price increases caused by injustice market mechanism, the government may intervene in pricing. To achieve this purpose, it is necessary formation hisbah institutions with the aim of protecting the interests of buyers and sellers
\end{abstract}

Keywords : Ibnu Taymiyyah, thought, pricing, government, hisbah

\begin{abstract}
Abstrak
Perkembangan ekonomi Islam tidak lepas dari perkembangan historis peradaban Islam. Studi tentang sejarah pemikiran ekonomi dengan menganalisis deskripsi pemikiran ekonomi Ibn Taymiyyah dan sejarah mempengaruhi pemikiran ekonomi Ibn Taymiyyah. Menurut Ibn Taymiyyah penetapan harga itu baik, tetapi tidak absolut, karena harga ditentukan oleh kekuatan permintaan dan penawaran. Kasus lain, jika kenaikan harga adalah mekanisme pasar, pemerintah dapat melakukan intervensi dalam penetapan harga. Untuk mencapai tujuan ini, perlu untuk melindungi kepentingan pembeli dan penjual
\end{abstract}

Kata Kunci; Ibnu Taymiyyah, pemikiran, harga, pemerintah, hisbah

\section{PENDAHULUAN}

Pemikiran ekonomi yang banyak ditulis para ulama masa lalu kalau ditilik dari perkembangan dan kemajuan ilmu pengetahuan memiliki relevansi dengan perkembangan dan dinamika ekonomi melalui teori-teori ilmu ekonomi di era modern sekarang. Masalah-masalah harga dan perubahannya sudah dapat dijumpai dari berbagai pemikiran ekonom Muslim pada masa lampau hingga sekarang ini masih relevan dengan kondisi perekonomian global saat ini. Jika pada saat ini terkesan bahwa perkembangan pemikiran ekonomi Islam kurang dikenal dan kurang "menyentuh" 
dalam kehidupan masyarakat, hal itu dikarenakan kajian-kajian pemikiran ekonomi Islam kurang tereksploitasi di tengah dominasi ilmu ekonomi konvensional yang lebih mapan dan banyak digunakan, baik di negara maju maupun berkembang. Akibatnya, perkembangan ekonomi Islam yang telah ada sejak tahun $600 \mathrm{M}$, kurang begitu dikenal oleh masyarakat. Hal inilah yang menjadikan pemikiran-pemikiran ekonomi Islam kurang mendapatkan perhatian, sebab mereka tidak mendapat informasi yang memadai. Perkembangan ekonomi Islam tidak dapat dipisahkan dari perkembangan sejarah peradaban Islam itu sendiri. Walaupun sejumlah literatur tidak secara implisit menyebutkan keberadaan pemikiran ekonomi Islam, tetapi hal ini bukan berarti perkembangan ekonomi Islam tidak ada, karena dinamika dan geliat masyarakat Islam tatkala itu terus berjalan. Di samping itu, ekonomi bukanlah suatu disiplin ilmu yang spesifik, sehingga ada kesan terjadi dikotomi antara perkembangan ilmu tersebut dengan perkembangan sosial kemasyarakatan. Jika pemisahan itu terjadi, hal tersebut hanyalah karena pemisahan antara satu persoalan dengan persoalan lain dalam mencari keridhoan Allah SWT. ${ }^{1}$

Kajian pemikiran ekonomi Islam masa silam sangat besar peranannya terhadap perkembangan dan kemajuan pemikiran ekonomi di zaman modern sekarang ini. Sejarah membuktikan bahwa banyak pemikir Muslim merupakan penemu, peletak dasar dan pengembang dalam berbagai bidang kajian ilmu. Kontribusi pemikiran intelektual Muslim pada saat itu, dimulai dalam bidang kajian ilmu-ilmu social, filsafat, matematika, astronomi, biologi, kedokteran, sejarah, sosiologi, psikologi, sampai sastra termasuk ilmu ekonomi. Menurut Dawam Raharjo, ada dua macam sejarah ekonomi: 1) sejarah pemikiran ekonomi yang merefleksikan evolusi pemikiran tentang ekonomi pada suatu periode tertentu yang memberikan suatu gambaran adanya perbedaan ideologis yang mewarnai ekonomi suatu masyarakat, tokoh, atau bangsa, dan karenanya dapat diambil muatan nilai atau prinsip-prinsip dasar didalamnya bagi

\footnotetext{
${ }^{1}$ Nur Chamid, Jejak Langkah Sejarah Pemikiran Ekonomi Islam, (Yogyakarta: Pustaka Pelajar, 2000) hal. vi
} 
pengembangan teoritis; 2) sejarah perekonomian suatu bangsa atau masyarakat yang dibutuhkan dalam perencanaan strategi pembangunan suatu masyarakat. Sejarah pemikiran ekonomi, dapat dibedakan menjadi dua macam, yaitu: 1) sejarah yang memaparkan evolusi pemikiran dari suatu tokoh atau beberapa tokoh yang menitikberatkan pembahasan pada uraian pemikiran dengan maksud mengenali ideologi pemikiran, dan 2) sejarah yang menceritakan riwayat hidup tokoh-tokoh besar di bidang ekonomi yang menekankan pembahasan pada sejarah hidup yang mempengaruhi tokoh yang bersangkutan. ${ }^{2}$ Dalam makalah ini, penulis menggunakan kajian sejarah pemikiran ekonomi dengan menganalisa uraian pemikiran ekonomi Ibnu Taimiyah dan sejarah hidup yang mempengaruhi pemikiran ekonomi Ibnu Taimiyah.

\section{SEJARAH PEMIKIRAN EKONOMI ISLAM}

Ekonomi berbasis syari'ah ini sudah dimulai sejak Islam berdiri diatas landasan al-qur'an dan hadist dibawah pimpinan ekonom bijak yaitu Muhammad SAW. Setelah wafatnya perkembangan ekonomi Islam dibagi menjadi tiga fase :

Pertama, Tahap Dasar - 450. H. pada fase ini muncul ekonom-ekonom Islam seperti Abu Yusuf (182. H/798. M) dengan kitab al-Khorroj yang banyak membahas mengenai keuangan publik (public Finance) dan akuntansi syari'ah. Kemudian Muhammad bin al-Hasan (189. H/804. M) mengeluarkan kitab al-Iktisab fii al-rizqi alMustahab (tentang bagaimana mendapatkan penghasilan hidup yang bersih) dengan cara sewa-menyewa, perdagangan, pertanian dan industri dan kitab al-Ashl yang membahas mengenai jual-beli salam, kemitraan, dan bagi hasil (mudhorobah). Abu 'Ubaid dengan kitabnya al-Amwal yang menjelaskan tentang materi zakat, khums, dan fay'ie yang merupakan intervensi pemerintah atas keinginan masyarakat yang berlebihan. Mawardi dengan kitabnya Al-Ahkam alSulthoniyyah dan al-Din WadDunya yang membahas mengeni penerimaan negara dan perilaku individu sebagai produsen maupun konsumen.

\footnotetext{
${ }^{2}$ Dawam Raharjo dalam Nur Chamid, Jejak Langkah Sejarah., hal. 399
} 
Kedua, berkembang dengan lahirnya ekonom kenamaan yaitu al-Ghazali (451505. H/1055-111. M) dengan kitabnya Ihya' 'Ulum al-Din, Ushul al-Fiqh, alMusytasyfa, Mizan al-'amal, dan al-Tibr alMasbuk fii Nasihat al-Mulk. Dalam kitabnya ia menjelaskan tentang korupsi, evolusi uang, riba dan penimbunan barang. Sedangkan Ibn Taimiyah (661-728. H/1263-1328. M) dalam kitabnya al-Fatawa, alHisbah dijelaskan mengenai konsep harga yang adil sesuai landasan moral masyarakat. Lalu Ibn Kholdun (732-808. H/1332-1404. M) dalam buku Muqoddimah membahas tentang politik, sosial ekonomi Islam hingga perdagangan luar negeri.

Ketiga, lahirlah Shah Waliyullah (1114-1176. H/1703-1762. M) dengan kitabnya Hujjatullah al-Baligho yang menjelaskan tentang rasionalisasi pendapatan dan hingga dewasa ini muncul pakar ekonomi syari'ah seperti Umar Chapra, Najetullah Siddiqi dan lainnya. Di Indonesia seperti Syafi'ie Antonio, Dawam Raharjo dan para ekonom muslim lain. Pada periode pertengahan, kekuatan politik Islam mengalami kemunduran. Berbagai doktrin yang dikembangkan pada masa sebelumnya tidak efektif lagi dihadapkan kepada situasi obyektif. Maka pada periode pertengahan itu lahirlah pemikiran politik yang berbeda dengan sunni periode klasik, yang salah satunya dipresentasikan oleh Ibnu Taimiyah. Mengkaji pemikiran Ibnu Taimiyah sangat menarik, karena itulah di dalam makalah ini akan mendeskripsikan pemikiran politik Ibnu Taimiyah dan menganalisa latar belakang pemikirannya dengan pendekatan sosiopolitik. Kemudian mendeskripsikan secara analitik bagaimana pandangan Ibnu Taimiyah tentang politik, pemerintahan, kepemimpinan dan hakikat negara, di tengah suasana sejarah yang mengitari pemikirannya, serta relevansi gagasan politik Ibnu Taimiyah dalam konsep negara modern dengan cara menempatkan pemikiran Ibnu Taimiyah sebagai cermin dari pemikiran yang lahir di abad modern

\section{RIWAYAT SINGKAT IBNU TAIMIYAH}

Ahmad bin Abd al-Halim bin Abd al Salam bin Abd Allah bin al-Khidr bin Muhammad bin al-Khidir bin Ali bin Abd Allah bin Taimiyah al-Harani al-Damayqi atau Ibnu Taimiyah. Ibnu Taimiyah lahir di kota Harran pada tanggal 22 Januari 1263 
M, dan dibesarkan dalam lingkungan keluarga ulama besar mazhab Hambali. Tradisi lingkungan keilmuan yang baik ditunjang dengan kejeniusannya telah mengantarkan beliau menjadi ahli dalam tafsir, hadist, fiqih, matematika dan filsafat dalam usia masih belasan tahun. Selain itu beliau terkenal sebagai penulis, orator dan sekaligus pemimpin perang yang handal. ${ }^{3}$ Pada musa mudanya ia mengungsi karena penyerbuan suku Mongol, dan tiba di Damaskus bersama orang tuanya pada $1268 \mathrm{M}$ pada waktu itu ia hampir berusia enam tahun. Pada tahun $1282 \mathrm{M}$ ketika ayahnya meninggal Ibnu Taimiyah menggantikan kedudukan sang ayah sebagai Guru Besar Hukum Hambali dan memangku jabatan ini selama 17 tahun. ${ }^{4}$ Pemikiran ekonomi beliau banyak terdapat dalam sejumlah karya tulisnya, seperti majmu ${ }^{e e}$ Fatawa Syaikh Al-Islam, AsSiyasah Asy-Syar ${ }^{\text {ee }}$ iyyah fi Ishlah Ar-Ra ${ }^{e c}$ I wa ArRa ${ }^{e c} i y a h$, serta Al-Hisbah fi Al-Islam.

Selain karya tersebut Ibnu Taimiyah mengarang buku mencapai tiga ratus jilid, antara lain Iqtifa Al-Sirat Al-Mustaqim wa Mukhalaf asHab Al-jalum, Fatwa Ibnu Taimiyah, AlSarim Al-Maslul Al-Syatim Al-Rasul, AlSarim Al-Maslul fi Bayan Wajibat AlUmmah Nahwa Al-Rasul, al-Jawab Al-Sahih li Man Baddala Din Al-Masih dan sejumlah buku lain di bidang fiqih. Ibnu Taimiyah meninggal dunia di Damaskus tahun $728 \mathrm{H}$ dan dikebumikan di pemakaman kaum sufi. ${ }^{5}$

SKETAS SETTING POLITIK, SOSIAL, dan EKONOMI PADA MASA IBNU TAIMIYAH

\section{Politik}

Sekitar 13 tahun sebelum Ibnu Taimi-yah lahir, Dinasti Mamluk membangun kekuasaan di Suriah dan Mesir. Penguasa pertama dari Dinasti Mamluk (1260-1383 M) dikenal dengan nama Bahrite Mamluks. Masa pemerintahan awal dinasti itu bersamaan dengan masa hidup Ibnu Taimiyah (1263-1328 M), ketika ia tinggal di Damaskus

\footnotetext{
${ }^{3}$ Heri Sudarsono, Konsep Ekonomi Islam, (Yogyakarta: Ekonosia, 2004), hal. 154

${ }^{4}$ Abdul Azim Islahi, Konsepsi Ekonomi Ibnu Taimiyah. (terj) Anshari Thayib. (Surabaya: PT. Bina Ilmu, 1997) hal. 15

${ }^{5}$ Nur Chamid, Jejak Langkah Sejarah., hal. 230
} 
maupun di Kairo. Baibar menjadi sultan Mesir pada tahun 1260-1277 M. Pada masanya, banyak ulama, ahli hukum tertarik pergi ke Mesir yang menjadi fokus dari per-kembangan dunia Islam dan pusat peng-kajian di dunia Islam pada saat itu.

Setelah Baibar meninggal dunia, Sultan Nasir Muhammad Qawalun menaiki tahta (1293-1341 M). Inilah masa emas bagi Dinasti Mamluk, Ia memperkenalkan sejumlah pembaruan politik dan ekonomi dan memperluas hubungan diplomatik dengan negara-negara tetangga. Ia sangat menghargai ulama para ulama dan kaum terpelajar. Pada masa ini, Ibnu Taimiyah mampu meraih pengalaman akademik, politik dan ekonomi. Sultan Nasir memberinya kedudukan yang tinggi di antara para ulama, setelah dia dijemput dari penjara akibat sejumlah kesalahpahaman, perbedaan dan perselisihan pendapatnya dengan sejumlah ahli hukum (ulama) yang menentang dirinya dan gagasan-gagasan-nya. ${ }^{6}$

\section{Sosial}

Struktur masyarakat Mamluk terbagi dalam beberapa kelas. Pertama, bangsa Mamluk, yaitu mereka yang seketurunan dengan penguasa, para pemimpin yang menduduki jabatan pemerintahan dan yang ikut berperang. Kedua, kaum serbanan (ahl al-imamah), yaitu mereka yang bekerja di sejumlah kantor pemerintahan. Ketiga, kelas para pedagang dan pengusaha, mereka sangat kaya raya karena berkembangnya sektor perdagangan. Selain ketiga kelas di atas, ada kelas masyarakat lainnya, yaitu: para buruh, perajin, pedagang kecil dan kaum miskin. Mayoritas di antara mereka adalah kaum fallahin (petani dan buruh tani). Kondisi mereka sangat buruk karena men-jadi sasaran dari berbagai pungutan pajak yang tak sesuai dengan tingkat pendapatan masyarakat di wilayah itu.

\section{Ekonomi}

Orang-orang Mamluk mengetahui bahwa stabilitas dan kesuksesan pemerintahannya sangat tergantung pada kekuatan ekonomi. Oleh karena itu mereka berusaha

\footnotetext{
${ }^{6}$ Abdul Azim Islahi, Konsepsi Ekonomi., hal. 15-18
} 
menggali sumber-sumber kesejahteraan, mengembangkan pertanian, perdagangan dan industri. Sektor pertanian memperoleh prioritas pertama masa itu sebagai sumber utama kesejahteraan masyarakat. Karena kehidupan masyarakat pada waktu itu sangat tergantung kepada hasil produksi pertanian. Sejumlah lahan tanah pada masa Dinasti Mamluk didistribusikan kepada para Amir sebagai bentuk iqta' (pengganti gaji atau tanah ganjaran) sebagai bentuk hadiah dari pemerintah. ${ }^{7}$

Masa Dinasti Mamluk berkembang berbagai macam jenis industri di Mesir dan Suriah, seperti: industri tekstil, logam, pem-bangunan kapal, pertukangan. Para sultan memberi kemudahan untuk perkembangan perdagangan domestik. Di setiap kota Mesir dan Suriah memiliki sejumlah pasar. Sedangkan untuk mengembangkan perda-gangan luar negeri, para sultan Mamluk membuat perjanjian persahabatan dengan negaranegara Eropa dengan mengembang-kan hubungan kerja sama. Untuk pengem-bangan perdagangan dan industri, lembaga hisbah memiliki peran sangat penting. Tugas utamanya melakukan pengawasan umum, khususnya kegiatan pasar dengan melakukan pengecekan timbangan, ukuran, kualitas barang, menjaga jual beli yang jujur dan menjaga agar harga selalu konstan. ${ }^{8}$

Sistem mata uang semasa Dinasti Mamluk menggunakan tiga jenis mata uang, yaitu uang dinar (emas), dirham (perak), dan fulus (tembaga). Uang dinar sangat langka, yang banyak digunakan adalah uang logam dari tembaga. Sirkulasi uang dirham selalu berfluktuasi, kadang langka di pasaran. Secara umum, sistem mata uang selama periode itu memang tidak stabil. Peredaran sejumlah besar mata uang tembaga fulus dan peningkatan proporsi dirham, menghilang-kan kepercayaan terhadap mata uang, mem-buat nilainya merosot dan mendorong ter-jadinya situasi inflatoar yang terus mem-buruk. ${ }^{9}$

Secara umum, Sultan-sultan Mamluk mengenakan pajak atas hasil pertanian, yang terbagi menjadi dua kategori: 1) pajak atas penggarapan tanah, 2) pajak atas kebun

\footnotetext{
${ }^{7}$ Abdul Azim Islahi, Konsepsi Ekonomi., hal. 29-35

${ }^{8}$ Ibid., hal. 36-41

${ }^{9}$ Ibid., $42-44$
} 
buah-buahan. ${ }^{10}$ Pajak dipungut oleh para muqta'. Terkadang para pejabat kesultanan diberi tanggungjawab untuk memungut pajak. Sistem pemungutan lainnya adalam daman, di mana damin (penjamin) mem-bayar sejumlah uang jaminan, tak peduli apakah hasil yang diperoleh dari penduduk nanti meningkat atau menurun. Ada sejumlah diwan (departemen) yang menangani berbagai pungutan pajak dan keuangan.

Misalnya: diwan al-rawatib, diwan al-sa'id, diwan al-jawali wal-mawarith alhasriyah, diwan al-kharaj, diwan al-hilali. Sebagai pusat koordinator dari diwandiwan tadi adalah Baitul Mal. Ada istilah lain, misalnya diwan al-nazar atau diwan nazar al-dawamin, yang secara bergantian merupakan bentuk lain dari Baitul Mal yang merupakan menteri keuangan. Seluruh rekening pen-dapatan dan pembelanjaan pemerintah diatur oleh departemen ini. Pendapatan dari kharaj diprioritaskan untuk pengeluaran militer, membiayai keluarga kerajaan, pemerintahan raja, para menteri, gubernur, wazir, hakim, pengawas diwan, akuntan, para penulis, penyediaan pelayanan umum seperti: dam, kanal, sekolah dan rumah sakit menjadi tanggungjawab pemimpin departemen ang-garan pembelanjaan umum. ${ }^{11}$

Pandangan Ibnu Taimiyyah tentang masalah ekonomi sangat jelas. Seluruh kegiatan ekonomi dibolehkan, kecuali apa yang secara tegas dilarang oleh syari'at. Dalam batasan larangan syari'at itu, semua orang mengetahui hal itu demi kebaikan bagi mereka dan mereka bebas melakukan transaksi, membuat kontrak atau mengerjakan berbagai masalah keduniaan dengan cara yang adil dan jujur. Hal ini mengikuti doktrin Islam pokok dari tauhid dan secara wajar mementingkan keadilan. Berkaitan dengan keadilan ini, beliau menulis, "Keadilan berkait dengan tauhid dan tauhid merupakan fondamen dari keadilan. Inilah yang memberikan keunggulan berkaitan dengan korupsi, yang merupakan dasar dan fondasi dari ketidakadilan.

\footnotetext{
${ }^{10}$ Abdul Azim Islahi, Konsepsi Ekonomi., hal. 41

${ }^{11}$ Ibid., hal. 51-53
} 


\section{PEMIKIRAN EKONOMI IBNU TAIMIYAH}

\section{Kompensasi dan Harga}

Dua istilah yang sering ada dalam pembahasan Ibnu Taimiyah tentang masalah harga, yaitu: 1) Kompensasi yang setara ('iwad al-mitsl) diukur dan ditaksir oleh halhal yang setara dan itulah esensi dari keadilan (nafs al-'adl); 2) harga yang setara (tsaman al-mitsl). Ibnu Taimiyah membeda-kan ada 2 (dua) jenis harga, yaitu: a) Harga yang tak adil/terlarang dengan b) harga yang adil/disukai. ${ }^{12}$ Harga yang setara itu sebagai harga yang adil. Jadi dua kata: "adil" dan "setara" digunakan saling mengganti. ${ }^{13}$

Konsep Ibnu Taimiyah tentang kom-pensasi yang adil ('iwad al-mitsl) dan harga yang adil (tsaman al-mitsl) tidaklah sama. Kompensasi yang adil adalah penggantian sepadan yang merupakan nilai harga yang setara dari sebuah benda menurut adat kebiasaan. Kompensasi yang setara diukur dan ditaksir oleh hal-hal yang setara tanpa ada tambahan dan pengurangan. Penggunaan kata kompensasi yang adil setara untuk membongkar masalah moral atau kewajiban hukum berkaitan dengan barang-barang, dan bukan merupakan kasus nilai tukar, tetapi sebagai kompensasi atau pelaksanaan sebuah kewajiban. ${ }^{14}$ Sedangkan harga yang adil adalah nilai harga di mana orang-orang menjual barangnya dapat diterima secara umum sebagai hal yang sepadan dengan barang yang dijual itu ataupun barang yang sejenis lainnya di tempat dan waktu tertentu. Keadilan yang dikehendaki oleh Ibnu Taimi-yah berhubungan dengan prinsip la dharar yakni tidak melukai dan merugikan orang lain sehingga dengan berbuat adil akan mencegah terjadinya tindak kezaliman.

Harga yang setara menurut Ibnu Taimiyah adalah harga baku (si'r), di mana penduduk menjual barang-barang mereka dan secara umum diterima sebagai sesuatu

\footnotetext{
12 Ibnu Taimiyah, Al-Hisbah fil Islam, (Kairo: Daar al-Sha’b, 1976), hal. 24-25; Abdul Azim Islahi, Economic Concepts of Ibn Taimiyah. London: Islamic Foundation, 1988) hal. 81

${ }^{13}$ Abdul Azim Islahi, Economic Concepts of Ibn Taimiyah. London: Islamic Foundation, 1988) hal. 81

${ }^{14}$ Euis Amalia, Sejarah Pemikiran Ekonomi Islam: Dari Masa Klasik Hingga Kontemporer, (Jakarta: Pustaka Asatrus, 2005), hal. 169
} 
yang setara dengan itu dan untuk barang yang sama pada waktu dan tempat yang khusus. ${ }^{15}$ Atau harga yang setara itu sesuai dengan keinginan atau lebih persisnya harga yang ditetapkan oleh kekuatan pasar yang berjalan secara bebas antara penawaran dan permintaan. Selain itu Ibnu Taimiyah meng-gambarkan perubahan harga di pasar "jika penduduk menjual barangnya dengan cara yang normal (al-wajah al-ma'ruf) tanpa menggunakan cara-cara yang tidak adil, kemudian harga meningkat karena pengaruh kekurangan persediaan barang (misalnya karena menurunnya suplai/penawaran) atau meningkatnya jumlah penduduk (yaitu me-ningkatnya permintaan), itu semua karena Allah. Dalam kasus seperti itu, memaksa penjual untuk menjual barang mereka pada harga khususnya, merupakan paksaan yang salah (ikhrah bi ghoiri haqq). ${ }^{16}$

\section{Keuntungan yang setara (adil)}

Ibnu Taimiyah menganjurkan penjual berhak memperoleh keuntungan yang diterima secara umum (al-ribh al-ma'ruf) tanpa merusak kepentingannya dan kepentingan pelanggannya. ${ }^{17}$ Keuntungan yang adil adalah keuntungan normal yang secara umum diperoleh dari berbagai macam model perdagangan, tanpa saling merugikan. Ia tidak menyetujui tingkat dasar keuntungan yang tidaak biasa, bersifat eksploitatif atau situasi di mana masyarakat tak mengambil peduli pada kondisi pasar yang ada. ${ }^{18}$ Ia juga berpendapat bahwa seseorang yang mem-peroleh barang untuk menghasilkan penda-patan dan memperdagangkannya, diboleh-kan melakukan itu tetapi dia tidak boleh menarik ongkos dari orang yang membutuhkan untuk meraih keuntungan yang lebih tinggi ketimbang kebiasaannya (al-ribh al-mu'tad) dan sebaiknya tidak meningkatkan harganya bagi orang yang sangat membutuh-kan. ${ }^{19}$

\footnotetext{
${ }^{15}$ Ibnu Taimiyah, Majmu’ Fatawa Shaikh al-Islam, Vol. 29, (Riyadh: Matabi' al-Riyad, 1963) hal. 345; Abdul Azim Islahi, Economic Concepts., hal.83

${ }^{16}$ Ibnu Taimiyah, Al-Hisbah., hal. 25, 42; Abdul Azim Islahi, Economic Concepts ., hal. 83

${ }^{17}$ Ibid., Ibnu Taimiyah, hal. 37; Abdul Azim Islahi, hal. 85

${ }^{18}$ Ibnu Taimiyah, Majmu’ Fatawa., Vol. 25, hal. 299; Abdul Azim Islahi, Economic Concepts., hal.86

${ }^{19}$ Ibid, Ibnu Taimiyah, hal. 501; Abdul Azim Islahi, hal. 86
} 


\section{Mekanisme Pasar}

Ibnu Taimiyah memiliki pandangan yang jernih bagaimana dalam sebuah pasar bebas, harga dipengaruhi oleh kekuatan permintaan dan penawaran. ${ }^{20}$ Ia berkata: "Naik dan turunnya harga tidak selalu berkait dengan kezaliman (zulm) yang di-lakukan seseorang. Sesekali, alasannya ada-lah adanya kekurangan dalam produksi atau penurunan impor dari barang-barang yang diminta. Jadi, jika membutuhkan peningkatan jumlah barang, sementara kemam-puannya menurun, harga dengan sendirinya akan naik. Di sisi lain, jika kemampuan penyediaan barang meningkat dan permintaannya menurun, harga akan turun. Kelang-kaan dan kelimpahan tidak mesti diakibatkan oleh perbuatan seseorang. Bisa saja ber-kaitan dengan sebab yang tidak melibatkan ketidakadilan. Atau, sesekali, bisa juga di-sebabkan ketidakadilan. Maha besar Allah, yang menciptakan kemauan pada hati manusia. ${ }^{21}$

Ibnu Taimiyah mengidentifikasikan beberapa faktor yang berpengaruh terhadap permintaan dan konsekuensinya terhadap harga, yaitu: 1) keinginan penduduk atas jenis yang berbeda dan sesekali berubah-rubah, 2) perubahannya tergantung pada jumlah para peminta, 3) meluasnya jumlah dan ukuran dari kebutuhan baik kecil atau besar berpengaruh terhadap menguat atau melemahnya tingkat kebutuhan atas barang, 4) harga berubah-rubah sesuai dengan siapa saja pertukaran barang itu dilakukan, 5) harga dipengaruhi oleh bentuk alat pemba-yaran yang digunakan dalam jual beli, 6) disebabkan oleh tujuan dari kontrak adanya pemilikan oleh kedua belah pihak, 7) aplikasi yang sama berlaku bagi seseorang yang meminjam atau menyewa. ${ }^{22}$

\section{Regulasi harga}

Ibnu Taimiyah membedakan dua tipe penetapan harga yaitu: 1) Tidak adil dan tidak sah adalah memaksa penduduk menjual barang-barang dagangan tanpa dasar

\footnotetext{
${ }^{20}$ Adi Warman Azwar Karim, Sejarah Pemikiran Ekonomi Islam, (Jakarta: PT. Raja Grafindo Persada, 2004), hal. 160

${ }^{21}$ Ibnu Taimiyah, Majmu’ Fatawa., Vol. 29, hal. 583; Abdul Azim Islahi, Economic Concepts., hal.88-89

${ }^{22}$ Abdul Azim Islahi, Konsepsi Ekonomi., hal. 107-108
} 
kewajiban untuk menjual, merupakan tindakan yang tidak adil dan ketidakadilan itu dilarang; 2) Adil dan sah: saat pemerintah memaksa seseorang menjual barangbarangnya pada harga yang jujur, jika pen-duduk sangat membutuhkannya. ${ }^{23}$

Dalam menetapkan harga, tingkat tertinggi dan terendah bisa ditetapkan, sehingga kepen-tingan dua pihak, penjual dan pembeli ter-lindungi. Ibnu Taimiyah tidak menyukai kebijakan penetapan harga oleh pemerintah, jika kekuatan pasar yang kompetitif bekerja dengan baik dan bebas. Ia merekomendasi-kan kebijakan penetapan harga, dalam kasus terjadi monopoli dan ketidaksempurnaan mekanisme pasar. ${ }^{24}$

\section{Uang dan Kebijakan Moneter}

Fungsi uang menurut Ibnu Taimiyah sebagai alat tukar dan alat ukur dari nilai suatu benda, melalui uang itu dari sejumlah benda diketahui nilainya. ${ }^{25}$ Mengenai kebijakan moneter, Ibnu Taimiyah berpendapat bahwa pemerintah harus mencetak mata uang yang sesuai dengan nilai transaksi yang adil dari penduduk, tanpa keterlibatan kezaliman didalamnya. Dan juga para penguasa jangan memplopori bisnis mata uang dengan membeli tembaga kemudian mencetaknya menjadi mata uang koin, bahkan pemerintah harus mencetak mata uang dengan harga yang sebenarnya tanpa bertujuan mencari keuntungan apapun dari pencetakannya agar kesejahteraan publik terjamin. ${ }^{26}$

\section{a.Karakteristik dan Fungsi Uang:}

Secara khusus Ibnu Taimiyah menye-butkan dua utama fingsi uang yaitu sebagai pengukur nilai dan media pertukaran bagi sejumlah barang yang berbeda. Ia menyata-kan. "Atsman (harga atau yang dibayarkan sebagai harga, yaitu uang) dimaksudkan sebagai pengukur nilai barang (mi'yar al-amwal) yang dengannya jumlah nilai barang-barang (maqadir al-amwal) dapat diketahui; dan uang tidak pernah

\footnotetext{
${ }^{23}$ Ibid., hal. 117-118

${ }^{24}$ Adi Warman Azwar Karim, Ekonomi Islam Suatu Kajian Ekonomi Makro, (Jakarta: IIIT Indonesia, 2002), hal. 30

${ }^{25}$ Ibnu Taimiyah, Majmu’ Fatawa., Vol. 29, hal. 472; Abdul Azim Islahi, Economic Concepts., hal.139

${ }^{26}$ Ibnu Taimiyah, Majmu’ Fatawa., Vol. 29, hal. 472; Abdul Azim Islahi, Economic Concepts., hal.141-142
} 
dimaksud-kan untuk diri mereka sendiri." Berdasarkan pandangannya tersebut, Ibnu Taimiyah menentang keras segala bentuk perdagangan uang, karena hal ini berarti mengalih-kan fungsi uang dari tujuan sebenarnya. Apabia uang dipertukarkan dengan uang yang lain, pertukaran tersebut harus dilakukan secara simultan (taqabud) dan tanpa penundaan (hulul). Dengan cara ini, seseorang dapat mempergunakan uang sebagai sarana untuk memperoleh berbagai kebutuhannya.

\section{b. Penurunan Nilai Mata Uang}

Ibnu Taimiyah menentang keras ter-jadinya penurunan nilai mata uang dan percetakan mata uang yang sangat banyak. Ia menyatakan, Penguasa seharusnya mencetak fulus (mata uang selain dari emas dan perak) sesuai dengan nilai yang adil (proporsional) atas transaksi masyarakat, tanpa menim-bulkan kezaliman terhadap mereka. Pernya-taan tersebut memperlihatkan Ibnu Taimiyah memiliki beberapa pemikiran tentang hubu-ngan antara jumlahh mata uang, total volu-me transaksi dan tingkat harga. Pernyataan-nya tentang volume fulus harus sesuai dengan proporsi jumlah transaksi yang terjadi adalah untuk menjamin harga yang adil. Ia menganggap bahwa nilai intrinsik mata uang, misalnya nilai logam, harus sesuai dengan daya beli di pasar sehingga tdak seorang pun, termasuk penguasa, dapat mengambil untung dengan melebur uang tersebut dan menjual dalam bentuk logam atau mengubah logam tersebut menjadi koin dan memasukkannya dalam peredaran mata uang.

\section{c. Mata Uang yang Buruk Akan Menyingkirkan Mata Uang yang Baik.}

Ibnu Taimiyah menyatakan bahwa uang yang berkualitas buruk akan menying kirkan mata uang yang berkualitas baik dari peredaran. Ia menggambarkan hal ini sebagai berikut. "Apabila penguasa membatal-kan pengggunaan mata uang tertentu dan mencetak jenis mata uang yang lain bagi masyarakat, hal ini akan merugikan orangorang kaya yang memiliki uang karena jatuhnya nilai uang lama menjadi hanya sebuah barang. Ia berarti telah melakukan kezaliman karena menghilanhkan nlai tinggi yang semuka mereka miliki. Lebih daripada itu, apabila nilai intrisik mata uang tersebut berbeda, hal iniakan menjadi sebuah sumber keuntungan bagi penjahat untuk mengum- 
pulkan mata uang yang buruk dan menu-karnya dengan mata uang yang baik dan kemudian mereka akan membawannya kedaerah lain dan menukarkannya dengan mata uang yang buruk di daerah tersebut untuk dibawa lagi kedaerahnya. Dengan demikian, nilai barang-barang masyarakat akan menjadi hancur. Pada pernyataan tersebut, Ibnu Taimiyah menyebutkan akibat yang terjadi atas masuknya nilai mata uang yang buruk bagi masyarakat yang sudah trlanjur memilikinya. Jika mata uang ter-sebut kemudian dinyatakan tidak berlaku lagi sebagai mata uang, berarti hanya diperlakukan sebagai barang biasa yang tidak memiliki nilai yang sama dibanding dengan ketika berfungsi sebagai mata uang. Disisi lain, seiring dengan kehadiran mata uang yang baru, masyarakat akan memper-oleh harga yang lebih rendah untuk barang-barang mereka.

Ibnu Taimiyah juga berpendapat bahwa: "Jika penguasa membatalkan penggunaan mata uang koin tertentu dan men-cetak jenis mata uang lain untuk penduduk, itu akan merugikan orang-orang kaya yang memiliki uang, karena jatuhnya nilai mata uang lama menjadi sekedar barang dagangan biasa. Berarti pemerintah bertindak zalim kepada mereka dengan menghilangkan nilai tinggi sebenarnya yang mereka miliki. Lebih dari itu, jika nilai intrinsik dari koin itu berbeda, itu bisa menjadi sumber keuntungan bagi seseorang untuk mengumpulkan mata uang koin yang lebih buruk dan ditukarkannya dan kemudian membawanya ke negeri lain untuk ditukar lagi nilainya untuk dibawa ke negerinya. Akibatnya, barang-barang milik penduduk akan menjadi hancur. ${ }^{27}$

\section{Kerjasama}

Ibnu taimiyah membagi seluruh tran-saksi dan kegiatan ekonomi menjadi dua kategori: 1) transaksi yang berpijak pada asas keadilan dan, 2) yang berpijak asas kedermawanan dan manfaat. Transaksi yang berpijak pada asas keadilan, ada dua kategori: a. transaksi melalui pertukaran, dan b. transaksi melalui kerjasama. Transaksi kerjasama ada dua kategori: a) kerjasama dalam kepemilikan, dan b) kerjasama dalam

\footnotetext{
${ }^{27}$ Ibid., Ibnu Taimiyah, hal. 469; Abdul Azim Islahi, Economic Concepts., hal.143
} 
kontrak yang terdiri dari: 1) syirkah al-'inan, 2) syirkah al-abdan, 3) syirkah al-wujuh, 4) syirkah al-mufawadhoh, 5) syirkah al-mudharabah. ${ }^{28}$

\section{Kebijakan ekonomi}

Menurut Ibnu Taimiyah negara ber-hak melakukan intervensi terhadap hak indi-vidual untuk kepentingan manfaat yang lebih besar, seperti: 1) menghapuskan kemiskinan, 2) pengawasan mekanisme pasar, 3) mengontrol ekspansi mata uang dan mengawasi penurunan nilai mata uang, dan 4) perencanaan ekonomi. ${ }^{29}$

\section{Institusi Hisbah}

Tujuan dari institusi Hisbah menurut Ibnu Taimiyah adalah untuk memerintahkan apa yang sering disebut sebagai kebaikan (al-ma'ruf) dan mencegah apa yang secara umum diketahui sebagai keburukan (al-munkar) di dalam wilayah yang menjadi kewenangan pemerintah untuk mengaturnya, mengadili dalam wilayah urusan umum khusus lainnya, yang tak bisa dijangkau oleh intitusi biasa. ${ }^{30}$

Seseorang yang diangkat untuk me-megang peran sebagai muhtasib haruslah memiliki integrasi moral yang tinggi dan kompeten dalam masalah hukum, pasar dan urusan industrial. Melalui hisbah, negara menggunakan lembaga itu untuk mengontrol kondisi sosio-ekonomi secara komprehensif atas kegiatan perdagangan dan praktikpraktik ekonomi, seperti: mengawasi indus-tri, jasa profesional, standarisasi produk, penimbunan barang, dan praktik riba. Selain itu, muhtasib juga perlu mengawasi perilaku sosial penduduk, pelaksanaan kewajiban agama, dan kerja pemerintahan. Sedangkan fungsi ekonominya terdiri dari: 1) memenuhi dan mencukupi kebutuhan, 2) pengawasan terhadap industri, 3) pengawasan atas jasa, 4) pengawasan atas perdagangan. ${ }^{31}$

\footnotetext{
${ }^{28}$ Ibid., Ibnu Taimiyah, hal. 99

${ }^{29}$ Abdul Azim Islahi, Konsepsi Ekonomi., hal. 227-235

${ }^{30}$ Ibnu Taimiyah, Al-Hisbah., hal. 18;

${ }^{31}$ Abdul Azim Islahi, Konsepsi Ekonomi., hal. 239-241
} 


\section{Keuangan publik}

Pembahasan Ibnu Taimiyah tentang anggaran belanja lebih lengkap ketimbang tentang penerimaan. Pembagiannya atas penerimaan publik menjadi tiga kategori, yaitu: ghonimah, sadaqah dan fa'i; yang berkaitan pula dengan pembagian kategori serupa dalam pengeluaran publik. Ia mela-rang pengelakan pajak dan menasehati para pedagang untuk bersikap adil dalam penge-naan dan pengumpulan pajak meskipun itu atas pajak ilegal. Ia mengingatkan konse-kuensi dari pengenaan pajak yang diskriminatif dan tak adil. ${ }^{32}$

Sumber pendapatan yang paling pen-ting adalah zakat. Tetapi jumlah pokok kepentingan yang bisa dibiayai dari dana zakat itu sangat terbatas. Penerimaan dari ghanimah adalah tak menentu, hanya bisa diharapkan jika terjadi perang melawan orang-orang kafir. Sumber ketiga peneri-maan, yaitu fa'I termasuk di dalamnya jizyah, pajak atas tanah dan berbagai jenis pajak lainnya, tidak bisa digunakan untuk mencukupi seluruh kebutuhan pembiayaan untuk pertahanan keamanan dan pengembangan sepanjang waktu.

\section{KESIMPULAN}

Ibnu Taimiyah bukanlah seorang teo-ritis murni, juga bukan ahli sejarah ekonomi murni. Sikapnya lebih seorang dokter pra-ktik yang mendiagnosa penyakit dan mem-berikan resep untuk mengobati, seperti hal-nya dalam regulasi harga, menurut Ibnu Taimiyah penetapan harga oleh pemerintah adalah baik, tapi tidak bersifat absolut, karena sebenarnya harga ditetapkan oleh kekuatan permintaan dan penawaran. Lain halnya, apabila kenaikan harga terjadi akibat ketidakadilan mekanisme pasar, pemerintah boleh campur tangan dalam menetapkan harga.

Dua istilah yang sering ada dalam pembahasan Ibnu Taimiyah tentang masalah harga, yaitu: 1) Kompensasi yang setara ('iwad al-mitsl) diukur dan ditaksir oleh halhal yang setara dan itulah esensi dari keadilan (nafs al-‘adl); 2) harga yang setara

\footnotetext{
32 Abdul Azim Islahi, Konsepsi Ekonomi., hal. 280
} 
(tsaman al-mitsl). Ibnu Taimiyah membeda-kan ada 2 (dua) jenis harga, yaitu: a) Harga yang tak adil/terlarang dengan $b$ ) harga yang adil/disukai. ${ }^{33}$

Harga yang setara itu sebagai harga yang adil. Jadi dua kata: "adil" dan "setara" digunakan saling mengganti. Untuk mewujudkan kepentingan ini, perlu diben-tuknya institusi hisbah dengan tujuan melin-dungi kepentingan pembeli dan penjual. Kajian pemikiran ekonomi Ibnu Taimiyah, menunjukkan kedewasaannya dalam ber-pikir tentang masalah ekonomi dan keserius-annya terhadap keadilan mengenai kebijakan yang berkaitan dengan masalah ekonomi.

\section{DAFTAR PUSTAKA}

Amalia, Euis.2005. Sejarah Pemikiran Ekonomi Islam: Dari Masa Klasik Hingga Kontemporer, Jakarta: Pustaka Asatrus

Chamid, Nur. 2010. Jejak Langkah Sejarah Pemikiran Ekonomi Islam. Yogyakarta: Pustaka Pelajar.

http://yanasatia.wordpress.com, diakses pada tanggal 8 September 2011 pkl. 13.30.

Islahi, Abdul Azim. 1988. Economic Concepts of Ibn Taimiyah. London: Islamic Foundation

1997. Konsepsi Ekonomi Ibnu Taimiyah. (terj) Anshari Thayib. Surabaya: PT. Bina Ilmu.

Karim, Adi Warman Azwar.2002. Ekonomi Islam Suatu Kajian Ekonomi Makro, Jakarta: IIIT Indonesia

Grafindo Persada

2004. Sejarah Pemikiran Ekonomi Islam, Jakarta: PT. Raja

Sudarsono, Heri.2004. Konsep Ekonomi Islam, Yogyakarta: Ekonosia

Taimiyah, Ibnu.1963. Majmu’ Fatawa Shaikh al-Islam, Vol. 25\&29, Riyadh: Matabi' al-Riyad -1976. Al-Hisbah fil Islam, Kairo: Daar al-Sha'

\footnotetext{
${ }^{33}$ Ibnu Taimiyah, Al-Hisbah fil Islam, (Kairo: Daar al-Sha'b, 1976), hal. 24-25;
} 